\title{
PFEIFER, Jörg, Reform an Haupt und Gliedern. Die Auswirkungen des Trienter Konzils im Mainzer Erzstift bis 1626
}

\section{Christophe Duhamelle}

\section{CpenEdition}

\section{Journals}

Édition électronique

URL : http://journals.openedition.org/ifha/1483

DOI : $10.4000 /$ ifha. 1483

ISSN : 2198-8943

\section{Éditeur}

IFRA - Institut franco-allemand (sciences historiques et sociales)

Référence électronique

Christophe Duhamelle, «PFEIFER, Jörg, Reform an Haupt und Gliedern. Die Auswirkungen des Trienter Konzils im Mainzer Erzstift bis 7626 », Revue de l'IFHA [En ligne], Date de recension, mis en ligne le 01 janvier 1998, consulté le 22 septembre 2020. URL : http://journals.openedition.org/ifha/1483 ; DOI : https://doi.org/10.4000/ifha.1483

Ce document a été généré automatiquement le 22 septembre 2020.

(C)IFHA 


\title{
PFEIFER, Jörg, Reform an Haupt und Gliedern. Die Auswirkungen des Trienter Konzils im Mainzer Erzstift bis 1626
}

\author{
Christophe Duhamelle
}

1 Cette thèse étudie l'application des décisions du Concile de Trente dans l'Électorat de Mayence entre l'élection de l'archevêque Daniel Brendel von Homburg (1555) et la mort de Johann Schweickard von Cronberg (1626). J.P. procède selon un plan classique, confrontant pour chaque domaine (l'évêque, le prêtre, les Ordres et les laïcs) les décisions conciliaires et leur application locale. Cette perspective, privilégiant malgré les efforts de l'auteur le normatif sur l'application concrète, permet néanmoins un bon tour d'horizon des spécificités de la Réforme catholique dans les États ecclésiastiques.

2 Le caractère princier des archevêques de Mayence contribue à la lenteur des réformes. Il leur faut en effet ménager leurs puissants voisins, dont le très protestant Palatinat. En outre, élus par un chapitre cathédral recruté avant tout selon des critères de bonne noblesse, ils doivent longtemps ménager les réticences d'une aristocratie confessionnellement hésitante face à une affirmation décidée du renouveau catholique: le chapitre, après avoir concocté sa propre profession de foi simplifiée en 1572, s'oppose ainsi longuement à la généralisation de la profession tridentine, exigée en 1600 seulement du personnel enseignant et en 1602 des dignitaires de la cour électorale. Les entreprises de recatholicisation (par exemple après 1574 dans l'Eichsfeld), conditions d'une reprise en main territoriale et politique, sont menées avec beaucoup plus de vigueur que les réformes générales: les synodes, après une tentative en 1548, restent lettre morte, les visites pastorales demeurent rares et partielles, le baptême n'est réformé qu'en 1598, le clergé paroissial n'évolue vraiment qu'après 1595, il faut attendre 1615 pour voir la première ordonnance ecclésiastique générale et le séminaire épiscopal ne fut créé qu'en 1662. 
3 Face à ces atermoiements, les institutions romaines jouent un rôle de premier plan. À de multiples reprises, J.P. nous montre ainsi le nonce à Cologne (depuis 1583) formulant ses critiques envers le clergé local et obtenant parfois des décisions de l'archevêque. Par ailleurs, l'action de la Société de Jésus apparaît une fois de plus comme décisive. Le collège de Mayence, créé en 1561, accueille 160 élèves dès 1562 et 800 en 1580, suppléant ainsi à l'absence de séminaire. Les jésuites sont aussi à l'avant-garde des recatholicisations et $\mathrm{du}$ renouveau pastoral (missions, prédication), bien avant les Capucins qui ne s'installent à Mayence qu'en 1618.

4 C'est avec l'avènement de Johann Adam von Bicken (1601-1604) que l'Électorat entre vraiment en Réforme catholique. Le nouvel élu purge sa cour des protestants et donne tout son éclat à l'année sainte. La lenteur des réformes (plus dynamiques dans bien des évêchés territoriaux) est en définitive autant révélatrice du caractère oligarchique des États ecclésiastiques que des spécificités du catholicisme allemand en position de frontière confessionnelle. 